Section Editor

John J. Millichap, MD

\title{
A rare presentation of chronic intracranial hypertension with concurrent deafness and blindness
}

Mersedeh Bahr Hosseini, MD

Laura Stone McGuire, MD

Milena Stosic, MD

Heather E. Moss, MD, $\mathrm{PhD}$

Michael D. Carrithers, $\mathrm{MD}, \mathrm{PhD}$

Correspondence to

Dr. Carrithers: mcar1@uic.edu
Supplemental data at Neurology.org

\section{PEARLS}

- Isolated elevated intracranial pressure (ICP) commonly presents with false localizing signs.

- If elevated ICP remains unrecognized, it may lead to permanent neurologic deficits.

- Recognition of uncommon presentations, as well as radiologic signs of elevated ICP, is of paramount importance as prompt intervention minimizes morbidity.

\section{OY-STERS}

- Auditory neuropathy is an uncommon presentation of elevated ICP, possibly due to stretch of the vestibulocochlear nerve from the increased ICP.

- Petrous apex cephalocele and meningoceles are uncommon radiologic features of elevated ICP.

- Ischemic central retinal vein occlusion is a rare ophthalmologic manifestation of elevated ICP that may cause irreversible vision loss if the increased ICP remains unrecognized.

Isolated elevated intracranial pressure (ICP) classically presents with headache and papilledema without focal neurologic signs. ${ }^{1}$ Cranial nerve palsies, particularly abducens nerve palsy, have been described as false localizing signs. ${ }^{2,3}$ However, if elevated ICP remains unrecognized, it may lead to permanent neurologic deficits. We report a rare presentation of chronic idiopathic ICP elevation with bilateral sensorineural hearing loss (SNHL) and central retinal vein occlusions (CRVOs).

CASE PRESENTATION A 49-year-old Macedonian man, with a remote history of a motor vehicle accident that resulted in a leg amputation, presented to our emergency room with bilateral blindness and deafness.

Nine months earlier, he had presented to a local hospital in Macedonia with severe headache, blurry vision, and diffuse weakness. Per records, he had received a lumbar puncture (LP) with no recorded opening pressure and normal CSF findings. He was then empirically treated with plasma exchange for polyradiculoneuropathy based on an EMG/nerve conduction study.

At his presentation to our facility, he had diminished muscle strength in his bilateral upper extremities, left more than right. Deep tendon reflexes were absent on the left upper extremity and diminished elsewhere. His visual acuity was no light perception bilaterally with fixed dilated pupils. Funduscopic examination showed bilateral optic disc atrophy with mildly elevated margins consistent with atrophic papilledema and significant retinal hemorrhages consistent with CRVO. Fluorescein angiography of both eyes was also suggestive of CRVO (figure, A and B). Examination was also remarkable for hearing loss of the right ear and severely diminished hearing ability of the left ear. Audiogram showed severe bilateral low-frequency SNHL, right more than left. Auditory brainstem response was remarkable for inversion of the waveforms in response to a change in stimulus polarity, consistent with bilateral auditory neuropathies. Initial MRI of the brain was negative for any mass lesion or obstructive hydrocephalus. MRI of the internal auditory canals (IACs), however, was significant for petrous apex cephaloceles and protrusion of the meningoceles into the bilateral IACs (figure, B and C). Severe engorgement of bilateral optic veins with distention of perioptic subarachnoid space and atrophy of the optic nerves bilaterally was apparent on the MRI of the orbits (figure, E). Magnetic resonance venogram showed no evidence of venous sinus thrombosis or focal stenosis, although all venous sinuses were diffusely collapsed (figure, F). Subsequently, LP was performed with an opening CSF pressure of $45 \mathrm{~cm}$ $\mathrm{H}_{2} \mathrm{O}$. The details of CSF constituents are noted in table e-1 on the Neurology ${ }^{\circledR}$ Web site at Neurology.org. CSF bacterial and fungal cultures, extensive workup for vasculitides, and HIV antibody were also negative. EMG/nerve conduction study showed multilevel cervical radiculopathy with no evidence of polyneuropathy.

From the Departments of Neurology (M.B.H., M.D.C.), Neurosurgery (L.S.M.), and Ophthalmology (M.S., H.E.M.), University of Illinois at Chicago.

Go to Neurology.org for full disclosures. Funding information and disclosures deemed relevant by the authors, if any, are provided at the end of the article. 
Figure Fluorescein angiography and MRI findings
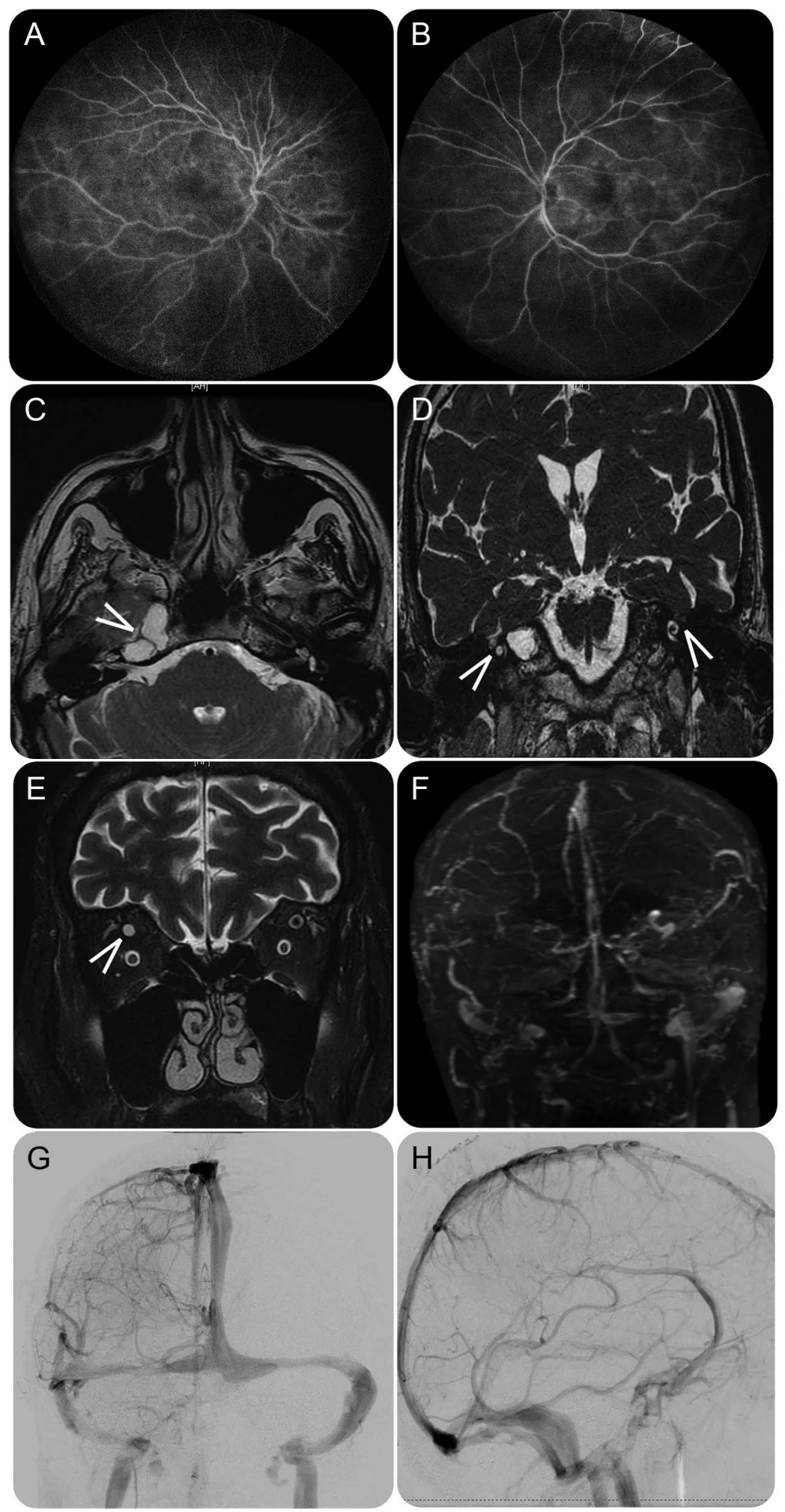

(A and B) Fluorescein angiography of the eyes; fluorescein wall staining suggestive of moderate to severe central retinal vein occlusion. (C) Axial MRI of the IAC; arrow shows right petrous bone cephalization. (D) Coronal MRI of the IAC; arrows show protrusion of meningoceles into the bilateral IACs. (E) Axial MRI of the orbit demonstrates severe engorgement of bilateral superior optic veins (arrow) with distention of perioptic subarachnoid space indicative of papilledema. (F) Magnetic resonance venography shows diffuse collapse of the venous sinuses. ( $G$ and $H$ ) Venous phase of postoperative cerebral angiogram; frontal and lateral views demonstrate resolution of the diffuse venous collapse. IAC = internal auditory canal.
No significant clinical improvement was observed after a large-volume LP and administration of highdose acetazolamide. Therefore, a ventriculoperitoneal shunt was inserted. Postoperatively, a cerebral angiogram was performed with resolution of the diffuse venous collapse on the venous phase (figure, $\mathrm{G}$ and $\mathrm{H}$ ). The acuity in the left ear improved, which was also evident on repeat audiogram at 1-month follow-up. His visual acuity improved to light perception bilaterally with resolution of optic disc elevation on funduscopic examination.

DISCUSSION Recognition of uncommon manifestations as well as radiologic signs of elevated ICP can be of great value, as delay in diagnosis may result in permanent deficits. The classic reported otologic features of elevated ICP are tinnitus and aural fullness; however, both conductive hearing loss and SNHL have been reported. ${ }^{4,5}$ Our patient presented with bilateral severe auditory neuropathies possibly due to stretch of the vestibulocochlear nerves from the increased ICP. 5 Protrusion of the meningoceles into the IACs was also deemed to be a contributing factor to the hearing loss in our case. Petrous apex cephaloceles and meningoceles have been described as rare radiologic signs of elevated ICP.., 7

Our patient showed significant improvement in auditory acuity in his left ear after the ventriculoperitoneal shunt insertion. However, his vision loss only minimally improved from no light perception to light perception bilaterally. Elevated ICP classically affects the visual system through papilledema. ${ }^{1}$ The profound vision loss in our patient was caused by optic neuropathy and bilateral ischemic CRVO, both of which are likely secondary to papilledema. While improvement following ICP normalization was minimal, this can be attributed to irreversible damage to the retina and ganglion cells sustained before presentation to our institution.

Extensive investigation for a secondary cause of elevated ICP in our patient was unrevealing. Given his clinical improvement following the surgical management of ICP, we conclude that this was the primary pathologic process. We present this case to highlight uncommon presentations of elevated ICP, so that prompt intervention can minimize morbidity.

\section{AUTHOR CONTRIBUTIONS}

Mersedeh Bahr Hosseini: primary writer of the manuscript. Laura Stone McGuire: writer of the manuscript. Milena Stosic: case data collection. Heather E. Moss: manuscript revision. Michael D. Carrithers: manuscript revision.

\section{STUDY FUNDING}

No targeted funding reported.

\section{DISCLOSURE}

M. Bahr Hosseini, L. Stone McGuire, M. Stosic, and H. Moss report no disclosures relevant to the manuscript. M. Carrithers has received research support from the Department of Veterans Affairs (merit award 2 I01 
BX000467-05) and Biogen within the last 2 years. Go to Neurology.org for full disclosures.

\section{REFERENCES}

1. Friedman DI, Liu GT, Digre KB. Revised diagnostic criteria for the pseudotumor cerebri syndrome in adults and children. Neurology 2013;81:1159-1165.

2. Dorman PJ, Campbell MJ, Maw AR. Hearing loss as a false localising sign in raised intracranial pressure. J Neurol Neurosurg Psychiatry 1995;58:516.

3. Larner AJ. False localising signs. J Neurol Neurosurg Psychiatry 2003;74:415-418.
4. Jindal M, Hiam L, Raman A, Rejali D. Idiopathic intracranial hypertension in otolaryngology. Eur Arch Otorhinolaryngol 2009;266:803-806.

5. Sismanis A, Callari RH, Slomka WS, Butts FM. Auditoryevoked responses in benign intracranial hypertension syndrome. Laryngoscope 1990;100:1152-1155.

6. Bialer OY, Rueda MP, Bruce BB, Newman NJ, Biousse V, Saindane AM. Meningoceles in idiopathic intracranial hypertension. AJR Am J Roentgenol 2014;202:608-613.

7. Moore KR, Fischbein NJ, Harnsberger HR, et al. Petrous apex cephaloceles. AJNR Am J Neuroradiol 2001;22: 1867-1871. 


\section{Neurology}

\section{Pearls \& Oy-sters: A rare presentation of chronic intracranial hypertension with concurrent deafness and blindness}

Mersedeh Bahr Hosseini, Laura Stone McGuire, Milena Stosic, et al.

Neurology 2016;87;e26-e28

DOI 10.1212/WNL.0000000000002868

\section{This information is current as of July 18, 2016}

\section{Updated Information \& Services \\ Supplementary Material}

\section{References}

Subspecialty Collections

\section{Permissions \& Licensing}

Reprints including high resolution figures, can be found at: http://n.neurology.org/content/87/3/e26.full

Supplementary material can be found at: http://n.neurology.org/content/suppl/2016/07/16/WNL.0000000000002 868.DC1

This article cites 7 articles, 4 of which you can access for free at: http://n.neurology.org/content/87/3/e26.full\#ref-list-1

This article, along with others on similar topics, appears in the following collection(s):

All Neuro-ophthalmology

http://n.neurology.org/cgi/collection/all_neuroophthalmology Idiopathic intracranial hypertension

http://n.neurology.org/cgi/collection/idiopathic_intracranial_hypertensi on

Optic nerve

http://n.neurology.org/cgi/collection/optic_nerve

Retina

http://n.neurology.org/cgi/collection/retina

Visual loss

http://n.neurology.org/cgi/collection/visual_loss

Information about reproducing this article in parts (figures,tables) or in its entirety can be found online at:

http://www.neurology.org/about/about_the_journal\#permissions

Information about ordering reprints can be found online:

http://n.neurology.org/subscribers/advertise

Neurology ${ }^{\circledR}$ is the official journal of the American Academy of Neurology. Published continuously since 1951 , it is now a weekly with 48 issues per year. Copyright @ 2016 American Academy of Neurology. All rights reserved. Print ISSN: 0028-3878. Online ISSN: 1526-632X.

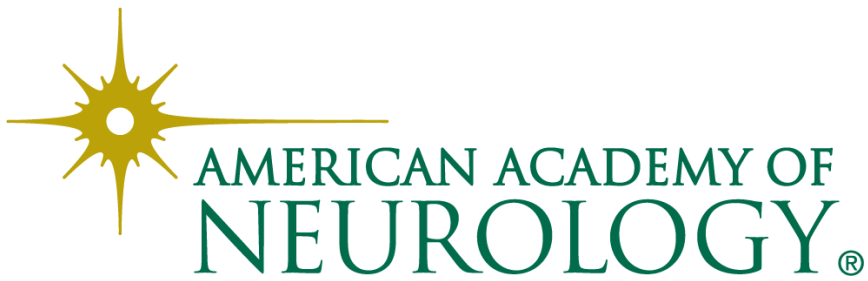

